\title{
THE ESSENCE AND STRUCTURE \\ OF THE SOCIO-CULTURAL EDUCATIONAL SPACE \\ OF THE UNIVERSITY
}

\section{Moskovchuk Olha ${ }^{1}$}

DOI: https://doi.org/10.30525/978-9934-571-89-3_19

The current stage of development of Ukrainian society is characterized by economic and political integration, which determines the processes aimed at creating a common European socio-cultural space. One of the topical issues that needs attention at this stage of development not only education but also society as a whole is the organization of socio-cultural educational space as a valuable aspect of the life of the individual.

In psychological and pedagogical literature, various aspects of the formalities and functioning of the socio-cultural educational space of the institution of higher education are highlighted: the educational system as a sociocultural phenomenon, the educational space of society as a socio-pedagogical space in the macro- and microsociety (D. Alkhimov, M. Fedorov); socio-cultural environment of the student, his activities (D. Chernyshov, O. Dmitrov); socio-cultural space of human formation and development (O. Marchenko). Scientists are trying to form a single approach to the definition of socio-cultural educational space as a compulsory component of the learning process.

The institution of higher education as a social institution is the socio-cultural space in which the young person not only acquires knowledge, but also the experience of life and interaction with other people and the world as a whole. In psychology and pedagogy, the category of "space" is considered as one of the important components of ontogenesis, which depends on the socio-economic conditions of life, the state of culture, human consciousness [3, p. 129]. On other content aspects, attention is paid to the interpretation of space by representatives of one of the areas of psychology of the environment. The main task of the environment, they consider the establishment of relationships between the personality, its internal world and the area where the subject of activity is located [4, p. 14].

In pedagogical studies, the category "space" actively began to be used only in the early 1990's and was presented initially as a metaphor for the preservation of the unity of positions in education. At this stage, it is used fairly widely, but very varied and multi-dimensional. In particular, the following types of space can be singled out: educational, educational, social, natural, university space, microdistrict, city, various activities (for example, gaming space), life, personal, space of opportunities having development potential.

Adolescence of young people occurs as a result of interaction with the social environment that affects this process through various social factors. The degree of

\footnotetext{
${ }^{1}$ Vinnitsa State Pedagogical University named after M. Kotsyubinsky, Ukraine 
development of the individual social environment, microscurrent can be considered through the concept of "social space of man", which is understood as a specific space of its capabilities, which allows you to meet the needs of contacts with the social world, as the degree of knowledge, development and appropriation of opportunities of the social environment based on its sub ' native perception [2, p. 28].

Students' social space is understood as a certain result of their social environment as a space of opportunities for shaping the social competence of future professionals, which allows them to meet their needs in contacts with the social world.

The social competence of students of a pedagogical institution implies openness to the world and responsibility for the surrounding social environment, the ability to cooperate in the student's team, the ability to establish productive contacts in order to solve the problems of self-education and self-education. In this context, the main idea of forming a university socio-cultural space is to create a humanistic orientation that promotes the holistic development and harmonious self-realization of the students, envisages the study, consideration and use by the team of the institution during the innovative pedagogical activities of those factors that positively influence the dynamics of the formation of the professionalism of future educators.

The main characteristics of the interaction of subjects of the socio-cultural space are: moral values that determine the overall background of cooperation between teachers and students; student activity in the educational process, containing elements of creativity; support for pedagogical initiatives and innovations; Personality-oriented principle of organization of educational process; expanding common goals of interaction; Expansion of the sphere of interaction outside of education; partnership: increasing the degree of personalization of interaction and creating favorable conditions for this; the ability of the teacher to "connect" to the personal experience of the student, as well as "connect" the student to his personal experience of interaction; positive emotional atmosphere: the expansion of conditions that allow the student to feel its significance as a participant in the interaction, the ability to evaluate the success of this interaction; raising the level of "security", "comfort" in the participants of the interaction "student-student", "student-group", "student-student self-government", "teacher-student") [1, p. 6; 2, p. 30; 5, p. 9].

In the socio-cultural educational space of the university, students and educators can actually actualize themselves, if at the same time they are active actors and properly use their potential capabilities, build relationships with the surrounding environment, intelligently determine the "field" of interaction. As a result of processes of development, self-development, self-organization enriched their cultural ties that contribute to the development of professionally valuable personal qualities.

Since the educational space of the formation of students' social competence is connected with a certain territory, it can be considered as a holistic, multidisciplinary and multifunctional educational complex, characterized by the presence of its systemforming components and system-determining elements [7, p. 407]. System-building includes educational institutions of all types and types that have a high educational potential, which is determined by the goals shared by the subjects of space; the only strategy vertically and horizontally, focused on the priorities of humanistic pedagogy; 
general territorial subculture; tasks of educational integration, formation of the educational community. System determinants are those institutions that specify the direction of space, determine its "face".

The peculiarities of the external sphere of the socio-cultural educational space of the University are determined by the support of the activity of the institution of higher education by the regional community, which is realized as participation in the implementation of educational tasks. At the same time, social institutions act as social partners, which take on the appropriate parts of responsibility for the quality of education. In actual practice, this is reflected in the existence of contractual relations between the university and other institutions and institutions of cultural and educational space.

In organizing the socio-cultural educational space of the university, which promotes the formation of social competence of students, it is advisable to distinguish between the components: the interaction of students and teachers, attitudes towards the outside world, cultural ties, activities. Another structural group is the components of implementation that ensure the functioning of the socio-cultural educational space - functions, forms of management and self-government, the organization of direct and feedback between the components. Orientation components - levels, areas and their own orientation - etermine the peculiarities of the functioning of the sociocultural space [5, p. 98].

Establishing links with various subjects of the socio-cultural educational space promotes innovative internal changes in the educational process of the university, reflected in the emergence of new opportunities for the implementation of project and research activities of students, the content of which corresponds to their professional intentions, the unification of the efforts of the university in strengthening the motives of the professional preparing students for future teachers.

Consequently, Ukrainian society needs modern educated, moral, pragmatic people who can make responsible decisions that are capable of cooperation, differ in dynamism, constructiveness, sense of responsibility. Today's requirements to a young specialist are related to the need to implement his social competence, the main factor in the formation of which is the socio-cultural space of the institution of higher education. The socio-cultural environment of the University is intended to prepare a future specialist to become an active member of a society competent in many areas of life, to gain experience in effective communication, to acquire skills for building constructive relations with social partners.

\section{References:}

1. Bekh I. D. (2013). Vykhovnyj prostir: orghanizacijno-zmistovi orijentyry [Educational space: organizational and content guidelines]. Ghirsjka shkola ukrajinsjkykh Karpat, no 10, pp. 3-14.

2. Ghaluzjak V. M. (2013). Obrazovatel'naya sreda kak faktor lichnostnogo razvitiya budushchikh uchiteley [Educational environment as a factor for the personal development of future teachers]. Proceedings of the Aktual'nye problemy pedagogicheskoy teorii i praktiki: materialy mezhdunarodnoy nauchnoy konferentsii (Moscow, Voronezh, 2013) (eds. Kirikova O.I., Smetanskiy N.I.), Voronezh: Voronezhskiy gosudarstvennyy pedagogicheskiy universitet, pp. 26-36. 
3. Yarmachenko, M. D. (Eds.). (2001). Pedaghoghichnyj slovnyk [Teaching Dictionary]. Kyiv: Pedahohichna dumka (in Ukrainian).

4. Rybka N. M. (2005). Jedynyj osvitnij prostir jak integhratyvna systema: Socialjno-filosofsjkyj analiz [The only educational space as an integrative system: Socio-philosophical analysis]. (PhD Thesis), Odesa: Pivdennoukrajinsjkyj derzhavnyj pedaghoghichnyj universytet imeni K. D. Ushynsjkogho.

5. Tkach T. V. (2008). Osvitnij prostir osobystosti: psykhologhichnyj aspekt [Educational space of personality: psychological aspect]. Zaporizhzhja: Instytut imeni Gh. S. Kostjuka APN Ukrajiny. (in Ukrainian)

6. Fel'dshteyn D. I. (1997). Sotsial'noe razvitie v prostranstve-vremeni detstva [Social development in the space-time of childhood]. Moscow: Moskovskiy psikhologo-sotsial'nyy institut: Flinta. (in Russian)

7. Kholkovsjka I. L., Moskovchuk O. S. (2018). Osoblyvosti sociokuljturnogho osvitnjogho prostoru jak chynnyka formuvannja socialjnoji kompetentnosti studentiv [Features of socio-cultural educational space as a factor in the formation of social competence of students]. Proceedings of the Suchasni informacijni tekhnologhiji ta innovacijni metodyky navchannja u pidghotovci fakhivciv: metodologhija, teorija, dosvid, problemy (Ukraine, Kiev-Vinnitsa, 2018), (eds. Zjazjun I.A. (gholova) ta inshi), Kyjiv-Vinnycja: TOV firma "Planer", pp. 405-409.

\footnotetext{
${ }^{1}$ Kharkiv Humanitarian-Pedagogical Academy, Ukraine
} 